\section{Weed Control with Hydrophobic and Hydrous Kaolin Clay Particle Mulches}

\author{
Fumiomi Takeda, ${ }^{1}$ D. Michael Glenn, ${ }^{2}$ and Thomas Tworkoski ${ }^{3}$ \\ U.S. Department of Agriculture, Agricultural Research Service, Appalachian \\ Fruit Research Station, 2217 Wiltshire Road, Kearneysville, WV 25430
}

Additional index words. primocane, corn gluten meal, napropamide, yield, herbicide, Rubus

\begin{abstract}
Three experiments were performed to determine the effect of amending the soil surface layer and mulching with hydrophobic kaolin particle on weeds and blackberry (Rubus subgenus Rubus Watson) plants. In the first study a processed kaolin material (product M-96-018, Engelhard Corporation, Iselin, N.J.), was incorporated in August into the top $3 \mathrm{~cm}$ of freshly roto-tilled field that had been in pasture the previous 5 years. The following spring, dry weight of weed vegetation in the control treatment was $219 \mathrm{~g} \cdot \mathrm{m}^{-2}$ and was significantly higher $(P=0.05)$ than the $24 \mathrm{~g} \cdot \mathrm{m}^{-2}$ harvested from the treated soil. In two other studies, planting holes for blackberry transplants were either 1) pre- or postplant mulched with a 2 - or 4-cm layer of $5 \%$ or $10 \%$ hydrophobic kaolin in field soil (w/w), or 2) postplant treated with a) napropamide, b) corn gluten meal, c) a product comprised of hydrous kaolin, cotton seed oil, and calcium chloride in water (KOL), d) hand weeded, or e) left untreated. Although untreated plots had $100 \%$ weed cover by the end of July, herbicide treatments, 4-cm deposition of hydrophobic kaolin particle/soil mulch, and KOL all suppressed weeds the entire establishment year. Preplant application of hydrophobic kaolin mulch and postplant application of KOL reduced blackberry growth and killed transplants, respectively. In year 2 , blackberry plants produced more primocanes that were on average $10-\mathrm{cm}$ taller in weed-free plots (herbicide, $4-\mathrm{cm}$ kaolin soil mulch, and mechanical weeding) than in weedy plots (control and 2-cm kaolin soil mulch). In year 3, yield was significantly lower in control plots $(1.5 \mathrm{~kg} / \mathrm{plant})$ than in plots that were treated with napropamide and 2- and 4-cm hydrophobic kaolin mulch, or hand weeded during the establishment year $(4 \mathrm{~kg} / \mathrm{plant})$. The results showed that $4-\mathrm{cm}$ hydrophobic kaolin mulch applied after planting can suppress weeds without affecting blackberry productivity. These kaolin products are excellent additions to the arsenal of tools for managing weeds in horticultural crops.
\end{abstract}

Weed management is an important component of small-fruit cropping systems, especially during the first 2 months following crop establishment (Forcella et al., 2003; Pritts and Kelly, 2001; Warmund et al., 1995). It is critical to control weeds in shallow-rooted small fruit crops such as blackberries, raspberries, and strawberries because of their high values, intensive culture, and lack of competitiveness with weed species. If left unchecked, weeds will compete with these crops for water and nutrients and adversely affect plant productivity and fruit quality (Trinka and Pritts, 1992). High populations of weeds may also become a habitat for insects and other pests. It is also important to manage weeds in crops such as blackberries and strawberries since visual appeal can be enhanced for pick-your-owncustomers (Masiunas et al., 1997)

Weed management in blackberry plantings

Received for publication 28 June 2004. Accepted for publication 29 Sept. 2004. We thank Ann K. Rose for her skilled technical assistance and Frank Forcella, Marvin Pritts, and Stephen Stringer for their critical review of this manuscript. Mention of trade names or commercial products in this publication is solely for the purpose of providing specific information and does not imply recommendation or endorsement of the products named or criticism of similar ones not mentioned by the U.S. Department of Agriculture.

${ }^{1}$ Research horticulturist. Corresponding author; e-mail ftakeda@afrs.ars.usda.gov.

${ }^{2}$ Soil scientist.

${ }^{3}$ Plant physiologist. al., 1995). These conventional mulches have beneficial effects on plant survival, growth, and fruit yield, but they are often expensive (Dale, 1989). Natural weed control products obtained from corn processing have been investigated for their efficacy in strawberry production (Dilley et al., 2002), but none have been evaluated in blackberry plantings.

The objectives of our studies were to evaluate hydrophobic and oil-based mulches and corn gluten meal for their potential to suppress weeds, and to determine the effect of pre and postplant applications of the hydrophobic mulch on subsequent blackberry plant growth and yield.

\section{Materials and Methods}

Studies were conducted at the Appalachian Fruit Research Station, Kearneysville, W.Va. ( $39^{\circ} \mathrm{N}$ lat., elevation $\left.158 \mathrm{~m}\right)$. Soil was a Hagerstown silt loam (fine, mixed, Typic Hapludalf).

Descriptions of field studies. In Study 1, a field that had been in pasture the previous 5 years was roto-tilled in August and $1-\mathrm{m}^{2}$ plots of untreated and treated soil were established in a paired $t$ test design with 6 replications. In the treated soil, M-96-018 hydrophobic kaolin particles were incorporated uniformly into the upper $3 \mathrm{~cm}$ of soil with hand cultivation. The concentration of M-96-018 kaolin was 3\% by weight in the upper $3 \mathrm{~cm}$ of soil. In the following spring, plant biomass was assessed to quantify the intensity of weed pressure. All weeds in a circular area of $0.12 \mathrm{~m}^{2}$ in the center of each plot were harvested and placed in a leaf dryer $\left(60^{\circ} \mathrm{C}\right)$ to determine the dry weight $\left(\mathrm{g} \cdot \mathrm{m}^{-2}\right)$ of vegetation.

In 2001, two blackberry plantings (Study 2 and 3) were established using about $30 \mathrm{~cm}$ tall, micro-propagated 'Apache' and 'Navaho' blackberry plants from plug trays (3.4-cm wide $\times 5.3$-cm long $\times 5.1 \mathrm{~cm}$ deep) purchased from Cedar Valley Nursery, Centralia, Wash.

For Study 2, a plot of land that was in blackberry cultivation, but roto-tilled in 1999 and left unmanaged until 2001, was used. In late April 2001, the soil was roto-tilled, hilled, and shaped to form a raised bed oriented in a north-south direction. The beds were then covered with a DeWitt Pro5 woven weed barrier fabric (DeWitt Co., Sikeston, Mo.). On 22 and 24 May, a $30 \times 30$-cm square hole was cut from the weed barrier at 1-m intervals (Fig. 1a). 'Apache' blackberry transplants were established in the middle of the holes cut from the weed barrier on 4 June 2001. The following experimental treatments were applied to exposed soil surface after the cut squares were removed: a) untreated control, b) postplant application of napropamide, c) hand weeding, preplant application of 2- and 4-cm hydrophobic mulch, and d) postplant application of sprayable kaolin material (KOL) which was comprised of $14 \%$ hydrous kaolin particles (Engelhard Corporation, Iselin, N.J.), $11 \%$ cotton seed oil, and 5\% calcium chloride in water.

Preplant application of hydrophobic mulch was applied by hand from 31 May to 1 June. 


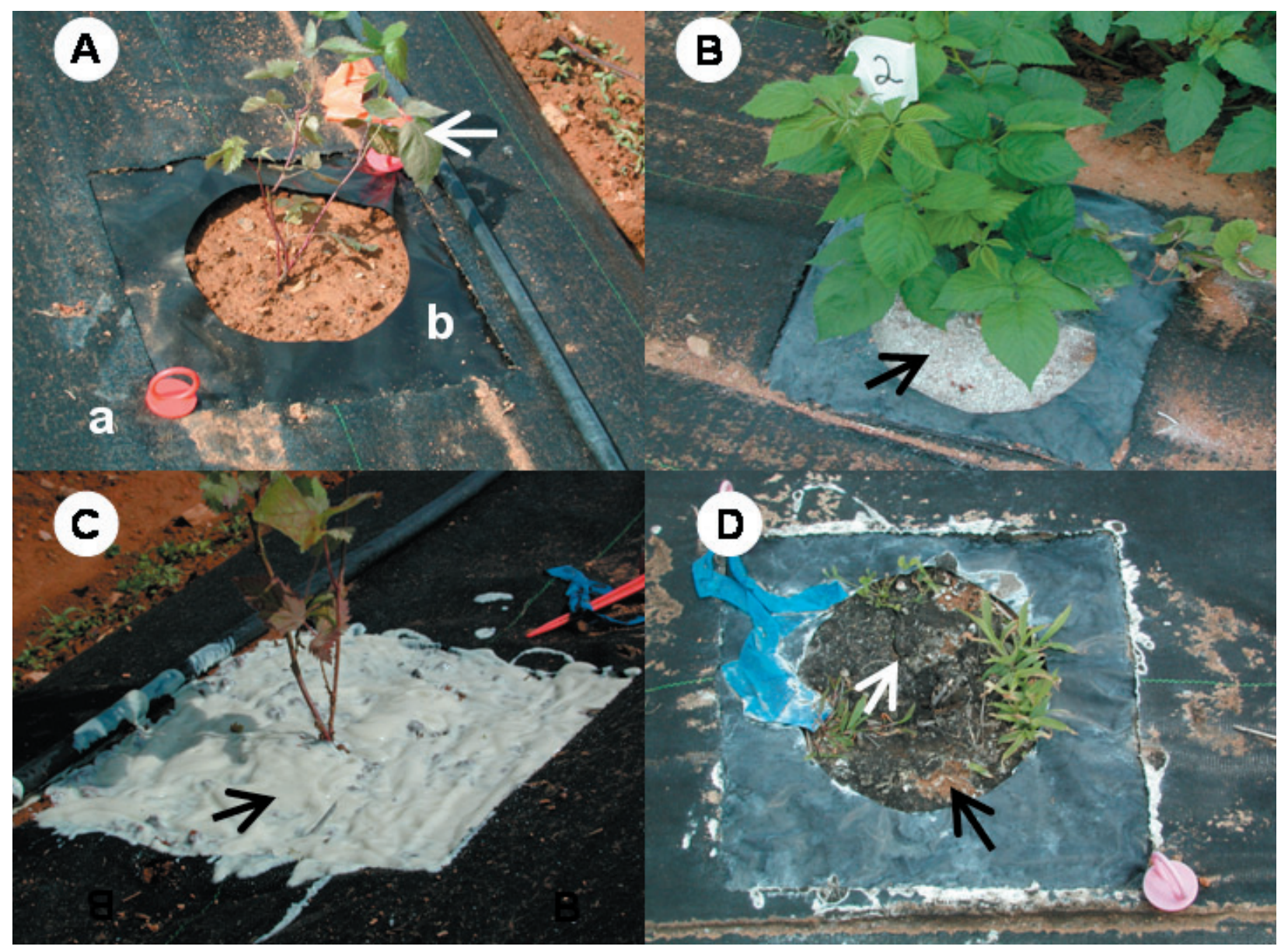

Fig. 1. Photographs show the basic experimental set-up. (A) Woven weed barrier (a) was placed over a preformed raised bed and a $900 \mathrm{~cm}^{2} \mathrm{square}$ was cut out at $75 \mathrm{~cm}$ spacing in the row. After a blackberry transplant (arrow) was in the ground a plastic collar (b) with a $400 \mathrm{~cm}^{2}$ circular opening in the middle was placed in the square opening. The edges were tucked under the barrier and stapled. (B) A close-up of a plant growing in a planting hole treated with the hydrophobic mulch (arrow). Note the different soil surface color from incorporating white hydrophobic kaolin particles. (C) A planting hole treated with KOL (arrow). (D) A KOL-treated planting hole shown in late May 2002 nearly one year after treatment. The sprayed material has blackened and hardened. Note that KOL is now cracked (white arrow) and flaked off in several places (black arrow) and weeds have emerged.

The hydrophobic mulch was produced by combining hydrophobic kaolin particles (M96-018, Engelhard Corporation, Iselin, N.J.) with un-sterilized, dry, sifted soil in a cement mixer. The concentration of M-96-018 kaolin particles was $5 \%$ by weight in the sifted soil. A $30 \times 30 \mathrm{~cm}$ frame with side walls made of $2 \mathrm{~cm}$ or $4-\mathrm{cm}$ wide flat bar was aligned with the square hole in the woven weed barrier fabric and hydrophobic mulch was poured onto the soil surface until it filled the frame to the top. A black plastic collar with $18 \mathrm{~cm}$ circular opening in the center was placed in the square hole and the edges were tucked under the weed barrier and stapled (Fig. 1b). To set blackberry transplants in this treatment, a $4.5 \mathrm{~cm}$ flat blade was pushed through the hydrophobic mulch to about a $5 \mathrm{~cm}$ depth and pulled to one side to create a planting hole. The hydrophobic mulch was displaced to expose the underlying soil so that the bottom surface (about $10 \mathrm{~cm}^{2}$ ) of the rooting media would be in direct contact with soil. The transplant was secured by hand pressing the mulch around the rooting medium (Fig. 1b). Napropamide (Devrinol $50 \mathrm{DP})$ treatment was applied to each of $30 \times 30 \mathrm{~cm}$ exposed soil surface with a hand sprayer at the rate of $9 \mathrm{~kg} \cdot \mathrm{ha}^{-1}$ on 28
June. In mechanically weeded plots, weeds were pulled by hand at about one month after planting and again in August. A volume of 100 $\mathrm{mL}$ of sprayable kaolin material (KOL) was applied to each of $30 \times 30 \mathrm{~cm}$ exposed soil surface with a hand sprayer.

For Study 3, a plot of land with blackberries from 1983 to 1996, but in which Kentucky-31 tall fescue (Festuca arundinacea Schreber) had been the dominant vegetation from 1997 to 2001 was roto-tilled in early June 2001 and soon after a raised bed was formed. The beds were covered with DeWitt Pro 5 weed barrier fabric and a $30 \times 30-\mathrm{cm}$ square was cut from the weed barrier at 1.0-m intervals (Fig. 1). 'Navaho' blackberry plants were transplanted on 12 June and 'Apache' blackberry plants were transplanted on 20 June. The following experimental postplant treatments were imposed: a) hand weeding, b) napropamide (described above), c) postplant application of 2- and 4-cm hydrophobic kaolin-soil mulch (described above but with $10 \% \mathrm{w} / \mathrm{w}$ ), and d) 3 applications at monthly intervals of corn gluten meal [Bio-weed, a.i. 98\% corn gluten meal (analysis: $10 \mathrm{~N}-1 \mathrm{P}-0 \mathrm{~K}$ ) from Bioscape, Inc., Petaluma, Calif.], applied at 9 and $18 \mathrm{~g}$ to each $30 \times 30 \mathrm{~cm}^{2}$ exposed soil surface area (equivalent to $1 \times$ and $2 \times$ recommended rate of $908 \mathrm{~kg} \cdot \mathrm{ha}^{-1}$ ). The hydrophobic mulch was applied by hand. A $30 \times 30 \mathrm{~cm}$ frame with 2- and 4-cm side walls was installed over the blackberry plant and was aligned with the edges of the hole cut in the fabric. Hydrophobic mulch was poured until it filled the frame to the top. A plastic collar with 18-cm-diameter opening in the center was placed in all the holes cut in the weed barrier fabric and the edges were tucked under the fabric and stapled (Fig. 1).

Weed assessment in Study 2 and 3. Weed control was estimated visually by two people as the percent of ground area of the planting hole covered by weeds on three occasions in 2001 and once in 2002, as described by Preusch and Tworkoski (2003). All weed species that emerged from soil in the planting hole were counted and identified. In mechanically weeded plots, emerged weeds were gently pulled out of soil after they were identified and an estimation of percent ground covered by weeds was recorded. In Study 3, weeds were gently pulled by hand in all plots after evaluation of weed abundance to eliminate weed competition and to evaluate direct effect of the weed control treatments on blackberry plants. Pulling weeds after each evaluation also permitted evaluation 
of new weed emergence and establishment throughout the season in all treatments.

Blackberry growth and yield. After the first growing season, blackberry plant survival was determined and primocanes of live plants were winter pruned at the soil line, counted, and their length and weight were measured. After the second growing season, following the recording of cane numbers and their lengths one plant in each plot was randomly selected in winter and all the canes were cut off near the soil line so that their pruning weights could be measured. In the third year, fruit were harvested from remaining un-pruned plants in two replicates of each treatment twice weekly to determine yield for the season.

Plotmanagement. Except for weed control, pest management in blackberry plantings was based on need and the plantings were fertilized and irrigated throughout the studies according to commercial recommendations (Demchak, 2000). In Study 2, canes were trained to the rotatable cross-arm trellis (Takeda et al., 2003), so only those canes that were more than about $1.5 \mathrm{~m}$ were retained for fruiting in year 3. The trellis system used in Study 3 was the conventional 2-m tall I-trellis. After the second growing season, up to nine canes on each plant were retained for fruiting in the third year. The blackberry experiments were conducted using a randomized complete block experimental design with six, four-plant and two-plant replications in 2001 and 2002, respectively. In 2003, fruit yield were collected from two out of the six replications.

Statistical analysis. In Study 1, treatment means were separated using the Bonferroni (Dunn) $t$ test (SAS Institute, Cary, N.C.). In Study 2 and 3, percentage data were transformed to square root-arcsine before statistical analysis. Data were subjected to PROC MIXED model analysis (SAS Institute, Cary, N.C.). Treatment means were separated using a DIFF option in the Proc Mixed model analysis $(P \leq 0.05)$.

\section{Results}

Weed control (Study 1). Incorporation of hydrophobic kaolin (M-96-018) into the upper $3-\mathrm{cm}$ of cultivated soil in summer suppressed weed growth through the following spring. Significantly less plant biomass was harvested in May from plots in which hydrophobic kaolin had been incorporated the previous summer. Dry weight of weed vegetation in the treated soil was only $24 \mathrm{~g} \cdot \mathrm{m}^{-2}$ and was significantly lower (paired $t$ test, $P \leq 0.05$ ) than $219 \mathrm{~g} \cdot \mathrm{m}^{-2}$ harvested from the untreated soil. The results from the first study showed that good weed control was possible with hydrophobic mulch.

Weed control (Study 2). Where blackberry plants were established in early June, weeds grew abundantly where herbicide or soil mulch was not applied (Table 1), covering as much as $79 \%$ of the ground within a month of planting and increasing to $100 \%$ by mid-July. The 2-cm-deep hydrophobic mulch treatment was marginally effective in suppressing crabgrass, Digitaria sanguinalis (L.) Scop. (Table 1). On average one plant of crabgrass established around each plant, but it grew rapidly to cover $50 \%$ of the ground by August. For the first month there were no weeds in plots treated with napropamide and 4-cm hydrophobic mulch. Later in the summer some weeds did emerge, but grew less vigorously than in other treatments and ground covered by weeds remained low $(<5 \%)$. By late summer, periodic hand weeding had reduced weed abundance to levels maintained by napropamide herbicide. After several weeks, KOL formed a hardened crust of blackened residue. The crust persisted for nearly a year on the soil surface. No weed seedlings penetrated through the hardened KOL in Year 1, but by the spring of Year 2, cracks developed in the hardened KOL crust and clover (Trifolium repens L.) and crabgrass seedlings emerged (Table 1 and Fig. 1). Weeds were essentially absent the following spring in plots that had previously been treated with napropamide. Where weeds did emerge, growth was not extensive, as no more than $18 \%$ of ground was covered by late May 2002 .

Numbers and species of weed plants that emerged in the planting holes differed among weed control treatments (Table 1). Crabgrass, nightshade (Solanum nigrum L), lambsquarters (Chenopodium album L.), and ground ivy were the most common weeds in control and handweeded plots where $>10$ seedlings of these species were counted around a blackberry plant.

Table 1. Effect of weed control treatment on the weed abundance during the 2001 summer and 2002 spring, and on the density of dominant weed species in the planting holes in 2001. 'Apache' blackberry plants were transplanted through the hydrophobic kaolin (5\% M96-018) mulch (Study 2). Weeds were pulled after each data collection in hand weeded plots.

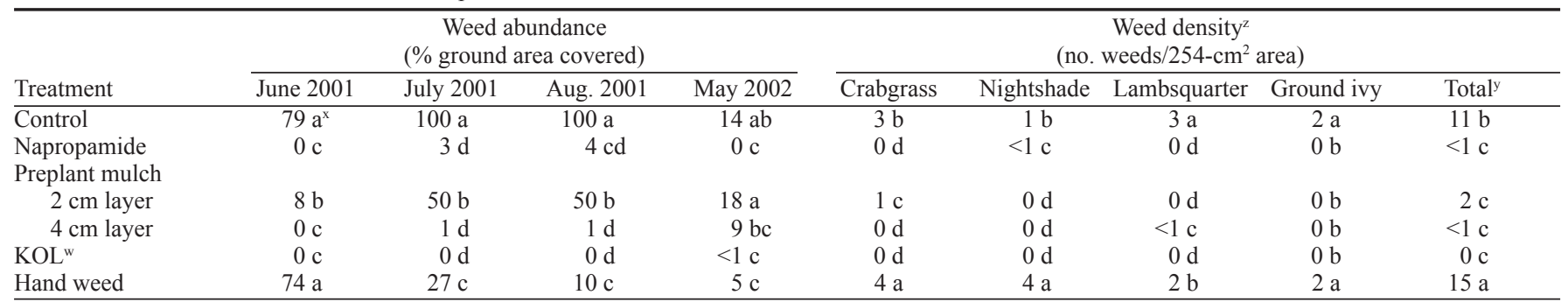

${ }^{2}$ Number of weeds that established within the $18 \mathrm{~cm}$ diameter opening in the plastic collar placed around each transplant.

${ }^{y}$ Total weed density included infrequent weeds that were found in less than two planting holes among 24 for each treatment. These weeds were carpetweed (Mollugo verticillata L.), dandelion (Taraxacum officianale Weber), spurge (Euphorbia supine Raf.), foxtail (Setaria glauca (L.) Bearub.), chickweed (Stellaria media (L) Gyrillo), pigweed (Amaranthus retroflexus L), henbit (Lamium amplexicaule L.), plantain (Plantago lanceolata L.), woodsorrel (Oxalis stricta L.), clover (Trifolium repens L.), purslane (Portulaca oleracea L.), geranium (Geranium maculatum L.), broadleaf dock (Rumex obtusifolius L.), and smartweed (Polygonum pensylvanicum L.).

"Values in columns followed by the same letter are not significantly different at $P \leq 0.05$.

wComposition: $14 \%$ hydrous kaolin, $11 \%$ calcium hydroxide, and $5 \%$ cotton seed oil in water.

Table 2. Effects of hand weeding, napropamide, corn gluten meal (Bio-weed), and postplant hydrophobic mulch (10\% M96-018) application on abundance and density of newly established weeds (Study 3) following establishment of 'Navaho' and 'Apache' blackberries in June 2001. All plots were hand weeded after each weed count to determine treatment effects on weed emergence and establishment.

\begin{tabular}{|c|c|c|c|c|c|c|c|c|c|}
\hline \multirow[b]{2}{*}{ Treatment } & \multicolumn{4}{|c|}{ Weed abundance ( $\%$ cover $)$} & \multirow{2}{*}{$\begin{array}{l}\text { No. weeds } \\
\text { pulled in } 01\end{array}$} & \multicolumn{4}{|c|}{ Weed density in May 2002 (no. weeds/254- $\mathrm{cm}^{2}$ plot) } \\
\hline & 19 July 2001 & 31 July 2001 & 24 Aug. 2001 & May 2002 & & Smartweed & Lambsquarter & Woodsorrel & Weeds (no.) $)^{\mathrm{z}}$ \\
\hline Control & $44 \mathrm{a}^{\mathrm{y}}$ & $59 \mathrm{a}$ & $6 \mathrm{a}$ & $18 \mathrm{a}$ & $11.8 \mathrm{a}$ & $0.3 \mathrm{a}$ & $0 \mathrm{a}$ & $0 \mathrm{a}$ & $1.1 \mathrm{a}$ \\
\hline Napropamide & $0 \mathrm{~d}$ & $0 \mathrm{c}$ & $0 \mathrm{a}$ & $11 \mathrm{a}$ & $<1 \mathrm{c}$ & $0.2 \mathrm{a}$ & $0 \mathrm{a}$ & $0.5 \mathrm{a}$ & $0.9 \mathrm{a}$ \\
\hline $9 \mathrm{~g} /$ hole & $28 \mathrm{~b}$ & $40 \mathrm{ab}$ & $2 \mathrm{a}$ & $18 \mathrm{a}$ & $6.8 \mathrm{~b}$ & $0.3 \mathrm{a}$ & $0 \mathrm{a}$ & $0 \mathrm{a}$ & $1.1 \mathrm{a}$ \\
\hline $18 \mathrm{~g} /$ hole & $17 \mathrm{bc}$ & $36 \mathrm{~b}$ & $1 \mathrm{a}$ & $19 \mathrm{a}$ & $4.7 \mathrm{~b}$ & $1.1 \mathrm{a}$ & $0.2 \mathrm{a}$ & $0.1 \mathrm{a}$ & $1.9 \mathrm{a}$ \\
\hline Postplant mulcl & & & & & & & & & \\
\hline $2 \mathrm{~cm}$ layer & $3 \mathrm{~cd}$ & $8 \mathrm{c}$ & $3 \mathrm{a}$ & $15 \mathrm{a}$ & $4.3 \mathrm{~b}$ & $0.8 \mathrm{a}$ & $0.1 \mathrm{a}$ & $0.2 \mathrm{a}$ & $1.8 \mathrm{a}$ \\
\hline
\end{tabular}

${ }^{ }$Number of weeds that established within the $18 \mathrm{~cm}$ diameter opening in the plastic collar placed around each transplant.

yalues in columns followed by the same letter are not significantly different at $P \leq 0.05$. 
Table 3. Effects of weed control treatment (Study 2) on plant mortality, number of primocanes per plant, cane height, and pruning weights of blackberry plants after the first and second year in the field and yield in the third year. Blackberry plants were transplanted through the hydrophobic mulch and weeds were not removed except in hand weeded plots. All data shown are on per plant basis.

\begin{tabular}{|c|c|c|c|c|c|c|c|c|}
\hline \multirow[b]{2}{*}{ Treatment } & \multicolumn{3}{|c|}{ Year $1(2001)$} & \multicolumn{4}{|c|}{ Year $2(2002)$} & \multirow{2}{*}{ 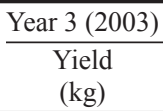 } \\
\hline & $\begin{array}{c}\text { Dead } \\
(\%)\end{array}$ & $\begin{array}{c}\text { Canes } \\
\text { (no.) }\end{array}$ & $\begin{array}{c}\text { Pruning wt } \\
(\mathrm{kg})\end{array}$ & $\begin{array}{l}\text { Canes } \\
\text { (no.) }\end{array}$ & $\begin{array}{l}\text { Cane ht } \\
\text { (m) }\end{array}$ & $\begin{array}{c}\text { Tall canes } \\
\text { (no.) }\end{array}$ & $\begin{array}{c}\text { Pruning wt } \\
(\mathrm{kg})\end{array}$ & \\
\hline Control & $0 \mathrm{c}^{\mathrm{y}}$ & $2.5 \mathrm{bc}$ & $0.03 \mathrm{c}$ & $4 \mathrm{~d}$ & $1.4 \mathrm{~b}$ & $1 \mathrm{~b}$ & $1.0 \mathrm{~b}$ & $1.5 \mathrm{~b}$ \\
\hline Napropamide & $0 \mathrm{c}$ & $3.4 \mathrm{ab}$ & $0.19 \mathrm{a}$ & $11 \mathrm{~b}$ & $1.4 \mathrm{~b}$ & $3 \mathrm{ab}$ & $1.8 \mathrm{a}$ & $4.3 \mathrm{a}$ \\
\hline \multicolumn{9}{|c|}{ Preplant hydrophobic mulch ${ }^{x}$} \\
\hline $2 \mathrm{~cm}$ layer & $4 \mathrm{c}$ & $3.1 \mathrm{ab}$ & $0.06 \mathrm{c}$ & $6 \mathrm{~cd}$ & $1.6 \mathrm{a}$ & $2 \mathrm{~b}$ & $1.3 \mathrm{~b}$ & $4.7 \mathrm{a}$ \\
\hline $4 \mathrm{~cm}$ layer & $13 \mathrm{~b}$ & $2.2 \mathrm{c}$ & $0.14 \mathrm{~b}$ & $8 \mathrm{bc}$ & $1.6 \mathrm{a}$ & $4 \mathrm{a}$ & $1.7 \mathrm{a}$ & $3.9 \mathrm{a}$ \\
\hline Hand weeding & $0 \mathrm{c}$ & $3.9 \mathrm{a}$ & $0.23 \mathrm{a}$ & $14 \mathrm{a}$ & $1.4 \mathrm{~b}$ & $3 a b$ & $1.7 \mathrm{a}$ & $3.7 \mathrm{a}$ \\
\hline $\mathrm{KOL}^{\mathrm{w}}$ & $75 \mathrm{a}$ & $---\mathrm{v}$ & --- & --- & --- & --- & --- & --- \\
\hline
\end{tabular}

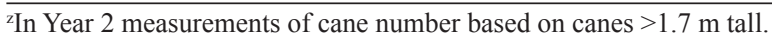

yalues in columns followed by the same letter are not significantly different at $P \leq 0.05$.

${ }^{x}$ Hydrophobic kaolin content was $5 \%$ by weight in sifted field soil.

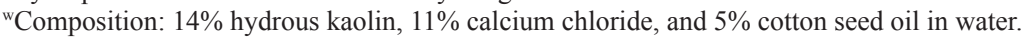

${ }^{v}$ Since $75 \%$ of plants in this treatment died shortly after planting, growth data were collected and are not included in the analysis.

Table 4. Effects of weed control treatment (Study 3) on plant mortality, number of primocanes per plant, cane height, and pruning weights of blackberry plants after the first and second year in the field and yield in the third year. Bio-weed was applied three times one month apart in 2001. Hydrophobic kaolin mulch was applied after blackberry plants were transplanted. All weeds were removed periodically in 2001 in all plots to eliminate weed competition and to evaluate new weed emergence. All data shown are on per plant basis.

\begin{tabular}{|c|c|c|c|c|c|c|}
\hline \multirow[b]{2}{*}{ Treatment } & \multicolumn{3}{|c|}{ Year 1 (2001) } & \multicolumn{2}{|c|}{ Year 2 (2002) } & \multirow{2}{*}{ 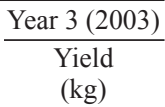 } \\
\hline & $\begin{array}{c}\text { Dead } \\
(\%)\end{array}$ & $\begin{array}{c}\text { Canes } \\
\text { (no.) }\end{array}$ & $\begin{array}{l}\text { Pruning wt } \\
(\mathrm{kg})\end{array}$ & $\begin{array}{l}\text { Canes } \\
\text { (no.) }\end{array}$ & $\begin{array}{l}\text { Tall canes } \\
\text { (no.) }\end{array}$ & \\
\hline Hand weeding & $0^{\mathrm{NS}}$ & $3.2^{\mathrm{NS}}$ & $0.37^{\mathrm{NS}}$ & $16.6^{\mathrm{NS}}$ & $8.6^{\mathrm{NS}}$ & $5.5^{\mathrm{NS}}$ \\
\hline Napropamide & 6 & 3.0 & 0.30 & 17.6 & 10.4 & 4.8 \\
\hline Bio-weed (9 g/hole) & 0 & 3.3 & 0.37 & 18.6 & 9.8 & 4.4 \\
\hline Bio-weed (18 g/hole) & 0 & 3.8 & 0.40 & 17.6 & 9.0 & 4.8 \\
\hline \multicolumn{7}{|l|}{ Postplant mulch } \\
\hline $2 \mathrm{~cm}$ layer & 6 & 3.0 & 0.43 & 16.8 & 12.6 & 4.1 \\
\hline $4 \mathrm{~cm}$ layer & 0 & 2.8 & 0.29 & 10.8 & 8.6 & 3.7 \\
\hline
\end{tabular}

NSNonsignificant at $P \leq 0.05$.

Fourteen additional weed species were identified but they occurred infrequently and in $<2$ out of 24 plots. By August 2001, less than two crabgrass plants grew in plots that were treated with napropamide or 2- and 4-cm hydrophobic mulches. In control plots one crabgrass grew to cover more than $50 \%$ of ground surface. In contrast, crabgrass did not grow rapidly in the 4-cm hydrophobic or napropamide-treated plots where weed abundance never exceeded $1 \%$ during the establishment year (Table 1).

In Spring 2002, ground area covered by weeds was higher in untreated control and 2$\mathrm{cm}$ hydrophobic mulch plots than in the other weed control treatments (Table 1). Lambsquarters was predominant at that time (data not presented). Once the soil surface around the plant became shaded by the blackberry canopy, subsequent weed growth was suppressed in all plots.

Weed control (Study 3$)$. Shortly after blackberry establishment, weeds grew abundantly in control plots but not in plots treated with napropamide and in plots that received postplant application of hydrophobic kaolin clay soil mulch (Table 2). However, by late August, weeds covered $<7 \%$ of ground surface in all treated plots because in this study, weeds were pulled from all plots twice in July. Total number of weeds pulled during the establishment year was 12 per plot in hand-weeded plots, followed by seven to four weeds in plots treated with 9 $\mathrm{g}$ and $18 \mathrm{~g}$ Bio-weed and 2-cm layer of hydrophobic mulch applied after planting. Best weed control was achieved with napropamide and 4-cm hydrophobic mulch applied after plant establishment. In these plots less than one weed emerged per planting hole and the ground coverage by weeds was $1 \%$ or less throughout the establishment year. Bio-weed was somewhat effective in preventing weed emergence since five to seven weeds were pulled as compared to 12 in the control. After July, weeds were essentially absent in all plots indicating that few weeds emerged and established in the late growing season (Table 2).

Blackberry growth and survival in Year 1 . Weed control treatments affected blackberry plant survival. No plant loss occurred in control or napropamide treated plots, but 4 and $13 \%$ of transplants died during the establishment year in plots in which blackberry plants were planted through 2- and 4-cm hydrophobic mulch, respectively (Table 3 ). In hydrophobic mulch the bottom surface of the rootball was exposed to soil, but the four side surfaces of the blackberry rootball media (about 64 $\mathrm{cm}^{2}$ ) were in contact with the mulch that was hydrophobic. About a month after planting the hydrophobic mulch was pulled back from the rooting media to determine whether new roots had developed into the hydrophobic mulch. No roots were observed growing into the surface layer of hydrophobic mulch and roots grew from the bottom of the rootball (data not presented).

In plots treated with KOL, $75 \%$ of blackberry plants died (Table 3 ). Although the transplants were shielded when KOL was applied onto the soil surface, spray drift may have occurred since blackberry plants began to die within a week. At that time we inspected the root system of these dying plants and saw no new roots on the surface of the rootball. Nine dead plants in KOL-treated holes were replaced with new transplants. No carryover effect was observed and all replacement plants grew satisfactorily (data not shown). This suggested that the transplants could be established after KOL has dried and crusted on the ground. Although many 30-cm-tall blackberry transplants were killed inadvertently, the study did show that KOL was a potent weed suppressant since it was able to maintain the transplant holes free of weeds for the entire year.

In Study 3, in which all weed control treatments were applied afterblackberry transplants were in the ground (Table 4), plant mortality was low (ranging from $0 \%$ to $6 \%$ ). Number of plants that died in plots with postplant hydrophobic mulch treatment was not different at $5 \%$ level of significance.

Blackberry growth during the establishment year was influenced by weed control treatment (Table 3). Pruning weight was greater in plots where weeds were not abundant or were suppressed either by chemical or mechanical methods (Table 3). Cane number was low where transplants were planted through $4 \mathrm{~cm}$ hydrophobic mulch and in control plots than in weeded plots. Since blackberry mortality was high in plots treated with KOL (Table 3), the statistical analysis did not include blackberry growth data taken in these plots in the establishment and subsequent years.

In Study 3, cane number and pruning weights did not differ significantly between 'Apache' and 'Navaho'blackberries $(P>0.10)$ so growth data for 'Apache' and 'Navaho' blackberries were combined for statistical analysis. Also, plant growth during the establishment year was not significantly affected by the weed control treatment because weeds that emerged were pulled periodically in all plots. Postplant application of hydrophobic mulch around small blackberry transplants appeared to have none of the deleterious effects as observed in Study 2 where the blackberry plants were transplanted through the hydrophobic mulch.

Blackberry growth in Year 2. In Study 2, weed control treatments imposed at planting affected the growth of blackberry plants in 2002. 
Reduced growth was consistently associated with the high weed abundance observed the previous season (Table 3). Plants that grew in plots with little or no weed pressure the previous year produced two to three times as many canes and twice as much pruning weight than plants that grew in weedy plots (e.g., hand weeded vs. control). Pruning weights ranged from about $0.95 \mathrm{~kg}$ for plants growing in untreated plots to more than $1.7 \mathrm{~kg}$ for plants that grew in plots where weeds were controlled during the establishment year. Canes of plants that were in plots with hydrophobic mulch were $20 \mathrm{~cm}$ taller than canes produced on plants in other treatments (Table 3 ). In plots in which weed pressure during the establishment year was low (Study 3), because weeds were pulled three times in July and August, weed control treatments imposed in 2001 had no effect on crop growth in 2002 (Table 4). Pruning weight and cane number in the second year did not differ significantly among the treatments (Table 4) as 'Apache' and 'Navaho' plants produced eight or more canes that were $1.7 \mathrm{~m}$ tall, which were retained and tied to trellis wires.

Fruit production in Year 3. In summer 2003, plants were hand harvested twice a week starting on 20 July for about 6 weeks. In Study 2, untreated control plots produced significantly less fruit ( $1.5 \mathrm{~kg} /$ plant $)$ than all other treatments plots where yields averaged more than $3.7 \mathrm{~kg} /$ plant (Table 3 ). No significant differences in the yield were detected among the treatments in Study 3 where weeds were pulled periodically in all plots to suppress weed competition during the establishment year (Table 4).

\section{Discussion}

This study demonstrated that several postplant weed management techniques provided excellent control of annual weed species. Napropamide, hand weeding, and hydrophobic mulches controlled weeds and were not detrimental to newly set blackberry transplants. As reported for raspberry transplants (Lawson and Wiseman, 1976; Trinka and Pritts, 1992), spring planted blackberry transplants did not tolerate weed competition well. In the establishment year plants in unmanaged, weedy plots grew half as much as those growing in weed-free planting holes. Although preplant hydrophobic mulch application and postplant application of KOL provided excellent weed control, these weed control measures resulted in unacceptable crop loss. Our findings suggested that crop survival can be improved if transplants are set in the ground after KOL has hardened and when hydrophobic mulches are applied after blackberry transplants are set in the ground. $\mathrm{KOL}$ warrants further testing as a potential weed management tool if plant mortality can be reduced by changing the application time.

Hydrophobic mulch was more effective than Bio-weed in controlling weeds and provided a level of suppression achieved with napropamide during the establishment year. The processed kaolin particles used in this study are extremely hydrophobic. The material is also easily dispersed by wind and can be car- ried away by rainwater unless it is mixed with another material. We combined M-96-018 with sifted, air-dried field soil to produce a mulching material that maintained a high hydrophobicity so that rain would not penetrate it, yet would be stable enough to persist on the soil surface for extended periods. This kaolin/soil mulch should be applied after blackberry plants are established to be an effective physical barrier for grass and dicot weeds. The shallow, 2-cm mulch treatment did not totally inhibit weed establishment. Grasses that established in 2-cm kaolin-soil mulch plots were likely to have come from seeds germinating in the moist soil underneath and subsequent growth upward through the thin part of the hydrophobic mulch. The 4-cm deep hydrophobic mulch has persisted for several seasons in the field. Although these plots did not receive weed control treatments in 2002 or 2003 , weeds were absent in 2003 (data not presented). Blackberry root systems were excavated in 2003 to determine root distribution of blackberry plants. The examination showed many roots had emerged from the crown and basal cane tissues, but none had grown into the kaolin-soil layer (data not presented). This suggests that if seedlings of annual plants emerge from a seed in the upper surface of hydrophobic mulch, they will probably lack the needed resources to extend their roots through $4 \mathrm{~cm}$ of mulch layer that is void of moisture.

An application of hydrophobic kaolin particles to the soil should have no adverse effect on animals and should not significantly alter the physical and chemical characteristics of soil. We have calculated that about 100 to 200 $\mathrm{kg}$ of processed kaolin particles is required to treat a hectare of blackberries. At these rates, we estimate that the clay content in the top 15 $\mathrm{cm}$ of soil will increase about $0.001 \%$ when the crop is removed and the field is tilled. Tilling the soil will break apart the hydrophobic layer and disperse kaolin particles into the soil. Once dispersed in the soil, the particles will no longer be a barrier to water. We postulate that, in time, the organic constituent of M-96-018 that coats the kaolin particles would be digested by soil microorganisms and that the hydrophobic nature of this material will decline.

This work demonstrated that hydrophobic mulch can be applied to suppress weeds. In plots where weeds were controlled with herbicide, mulches, or hand weeding during establishment, blackberry canes were more numerous and taller. The following years, benefits were expressed in greater cane density, better cane growth, and higher productivity. For example, 'Apache' plants in plots where weeds were controlled during the establishment year produced two or three canes that were taller than $1.7 \mathrm{~m}$ and developed more lateral branches in the second year of growth while plants in weedy untreated plots produced only one cane that was taller than $1.7 \mathrm{~m}$. This resulted in an increase in yield of 2 to 3 times over plants with high weed competition during the establishment year. Our findings clearly showed the importance of weed control during the first cropping year and are in agreement with the results of studies investigating the effects of weed competition on small fruit crops (e.g., strawberry, blueberry, and raspberry) (Forcella et al., 2003; Pritts and Kelly, 2001; Trinka and Pritts, 1992; Warmund et al., 1995).

Hydrophobic mulches appear to be an attractive alternative to the conventional herbicide treatment. Satisfactory results from the application of hydrophobic mulches are possible (e.g., excellent weed control during establishment year and no adverse effect on blackberry transplant mortality, growth, or fruit yield) when the 4-cm hydrophobic mulch is applied after the transplants are established. Preplant application of hydrophobic mulch reduced blackberry survival and subsequent growth. Shallower deposition of hydrophobic mulch did not suppress weeds. We conclude that incorporation of hydrophobic kaolin particles into soils at $3 \%$ to $10 \%(\mathrm{w} / \mathrm{w})$ range to a depth of 3 to $4 \mathrm{~cm}$ (Study 1) or hydrophobic kaolin particles that are premixed with sifted soil and applied around plants (Study 2 and 3) would prevent weeds from getting established in the mulched area. Further refinements in the method of applying hydrous kaolin mulch $(\mathrm{KOL})$ and its formulation are required to eliminate high mortality of blackberry plants observed in this study.

More studies are needed to determine what modifications will be required to use hydrophobic mulches with typical blackberry and raspberry transplants that have only 10 to $15 \mathrm{~cm}$ of succulent top growth. Growers have expressed their reluctance to control weeds with hydrophobic mulch by following the manual procedure that we have described in this study for mixing and application. A mechanized approach can be developed that collects soil from tilled strip of soil outside the mulched bed or from row aisles, combines it with kaolin, and dispenses the mulch into the transplant holes. More research is needed to develop an efficient means of applying mulch comprised of hydrophobic kaolin particles to blackberry transplants and other hydrophobic particle mulches in which field soil is not needed. Also, an economic evaluation of various components of new strategies for weed control described in this report will be performed to determine the practicality of the system for commercial small fruit growers. The goal of this research was to test the potential usefulness of new weed control techniques in blackberry. Several techniques showed promise and with further refinements they can be incorporated into various weed management strategies.

\section{Literature Cited}

Dale, A. 1989. Productivity in red raspberries, p. 185-228. In: J. Janick (ed.). Horticultural reviews. vol. 11. AVI Publ., Westport, Conn.

Demchak, K. 2000. Commercial berry production and pest management guide, 2000-2001. Pa. State Univ. College Agr. Sci AGRS 53.

Dilley, C.A., G.R. Nonnecke, and N.E. Christians. 2002. Corn-based extracts to manage weeds and provide nitrogen in matted-row strawberry culture. HortScience 37:1053-1056.

Forcella, F., S.R. Poppe, N.C. Hansen, W.A. Head, E. Hoover, F. Propsom, and J. McKensie. 2003. Biological mulches for managing weeds in transplanted strawberry (Fragaria $\times$ ananassa). 
Weed Technol. 17:782-787.

Lawson, H.M. and J.S. Wiseman. 1976. Weed competition in spring planted raspberries. Weed Res. 16:155-162.

Masiunas, J., M. McGiffen, C. Wilen, C. Bell, T. Lanini, J. Derr, and G. Kolasani. 1997. Integrated weed management in horticultural crops, p. 1-16. In: M.E. McGiffen, Jr. (ed.). Weed management in horticultural crops. ASHS Press, Alexandria, Va.

Monaco, T.J., S.C. Weller, and F.M. Ashton. 2002. Weed science: Principles and practices. 4th ed. Wiley, New York.

Neal, J.C., M.P. Pritts, and A.F. Senesac. 1990. Evaluation of preemergent herbicide phytotoxicity to tissue culture-propagated 'Heritage' red raspberry. J. Amer. Soc. Hort. Sci. 115:416-422.

Preusch, P.L. and T.J. Tworkoski. 2003. Nitrogen and phosphorus availability and weed suppression from composed poultry litter applied as mulch in a peach orchard. HortScience 38:1108-1111.

Pritts, M.P. and M.J. Kelly, 2001. Early season weed competition reduces yield of newly planted matted row strawberries. HortScience 36:729-731.

Takeda, F. and D.M. Glenn. 1988. Soil management for strawberries. The effect of killed sod mulch on soil erosion and bed deterioration in the first season. Adv. Strawberry Prod. 7:16-18.
Takeda, F., A.K. Hummell, and D.L. Peterson. 2003. Primocane growth in 'Chester Thornless' blackberry trained to the rotatable cross-arm trellis. HortScience 38:373-376.

Trinka, D. and M. Pritts. 1992. Micropropagated raspberry plant establishment as influenced by weed control practices, rowcover use, and fertilizer placement. J. Amer. Soc. Hort. Sci. 117:874-880.

Warmund, M.R., C.J. Starbuck, and C.E. Finn. 1995. Micropropagated 'Redwing' raspberry plants mulched with recycled newspaper produce greater yield than those grown with black polyethylene. J. Small Fruit Viticult. 3(1):67-73. 